УДК 665.6

С.В. ГАЛЬКО

Київський наиіональний торговельно-економічний університет

В.В.ТКАЧУК, О.Ю. РЕЧУН

Луцький національний технічний університет

\title{
ЕКСПОРТНО-ІМПОРТНИЙ ПОТЕНЦАЛ РИНКУ МОТОРНИХ ПАЛИВ УКРАЇНИ
}

\author{
S. GALKO \\ Kyiv National University of Trade and Economics \\ V. TKACHUK, O. RECHUN \\ Lutsk National Technical University
}

\section{EXPORT-IMPORT POTENTIAL OF THE MOTOR FUEL MARKET OF UKRAINE}

\author{
https://doi.org/10.36910/6775-2310-5283-2021-14-15
}

Мета. Аналіз розвитку ринку моторних палив в Україні та світі, дослідження імпортно-експортних можливостей Украӥни. Розгляд стану світового ринку моторних палив допоможе виявити динаміку, спрогнозувати розвиток та очінити сучасні потреби в такій продукиії.

Результати. Основна мета реформування паливного ринку - зниження імпортозалежності від Росії та ї̈ союзників з паралельним максимальним заміменням украӥнською продукцією. Головним завданням розвитку ринку моторних палив в Україні повинно бути збільшення попиту на бензин. Дуже важливим на сьогодні є зменшення споживання дизпалива - найпроблемнішого продукту з екологічної точки зору. Частково ие завдання може бути вирімена за рахунок балансування акцизів таким чином, щуоб на АЗС бензин став дешевще, ніж дизпаливо. Аналіз світового ринку моторних палив показав, щуо дизельне паливо імпортується краӥнами в 1,8 разів більще, ніж бензини, а в Украӥну - в 4 рази більше. Встановлено, щз найбільшими експортерами моторних палив у світі є США, Нідерланди, Росія, ОАЕ, свої позиції щороку зміџнює Китай.

Практична значимість. Розгляд стану світового ринку моторних палив допоможе виявити динаміку, спрогнозувати розвиток та оиінити сучасні потреби в такій продукиіі. Аналіз сучасних українських реалій стану ринку моторних палив дозволить окреслити шляхи розв'язання наявних проблем. В сучасних умовах загострення зовнішніх ризиків важливою передумовою зміџнення господарської самодостатності України було б підвищення енергетичної незалежності. Проте практика господарювання та реалії в енергетичному секторі економіки свідчать про наступне: через відсутність позитивних змін стосовно зменшення енергомісткості готової продукції $i$ збереження негативних тенденцій при 
виробництві енергоносіїв не забезпечено рімучих дій у питаннях послаблення залежності від зовнішніх джерел енергозабезпечення. Структури, які працюють в енергетичному секторі національного господарства, володіють достатньою концентрацією інвестиційного капіталу для повноцінної модернізації, реконструкції і технічного переоснащення технікотехнологічної бази вітчизняних нафтопереробних виробництв, а також суттєвого збільшення виробництва нафтопродуктів, не вистачає лише політичної волі краӥни розпочати серйозну реконструкцію вітчизняних НПЗ.

Ключові слова: нафтопереробна промисловість, бензин, дизельне паливо, експорт, isnopm.

Постановка проблеми у загальному вигляді та ії зв'язок із важливими науковими чи практичними завданнями. Основна мета реформування паливного ринку - зниження імпортозалежності від Росії та іiі союзників 3 паралельним максимальним заміщенням українською продукцією. Найбільш очевидною деформацією українського ринку $є$ неприродно висока частка споживання скрапленого газу - 33\% в балансі дорожніх палив [1]. Цінова перевага цього палива штучно сформований державою, фактично дотує імпорт LPG мінімальною ставкою акцизу, яка вчетверо нижче, ніж на бензин (52 євро проти 213,5 євро/1000л). У результаті український бензин залишається незатребуваним, на відміну від імпортного скрапленого газу. Головним завданням розвитку ринку моторних палив в Україні повинно бути збільшення попиту на бензин. Дуже важливим на сьогодні є зменшення споживання дизпалива - найпроблемнішого продукту з екологічної точки зору. Частково це завдання може бути вирішена за рахунок балансування акцизів таким чином, щоб на АЗС бензин став дешевше, ніж дизпаливо. Розумне співвідношення акцизних зборів та зниження цін на бензин внаслідок цього підвищить попит на продукт внутрішнього виробництва і дозволить замістити сумарно 1,5 млн. т імпортного скрапленого газу та дизельного палива лише за рахунок зміни споживання палив. В результаті Україна стане значно незалежнішою у сфері нафтопродуктозабезпечення, при цьому зберігатимуться механізми конкуренції з імпортом - тільки по бензинах частка українських виробників може досягти $70 \%$, на дизельне паливо - 35\%, скраплений газ - 50\%. Посилення внутрішньої нафтопереробки матиме потужний комплексний ефект, збільшивши завантаження нафтотранспортних і морських перевалочних потужностей.

Аналіз останніх досліджень, у яких започатковано вирішення проблеми. Проблемами якості моторних палив, підвищенню їх експлуатаційних 
властивостей присвячені праці таких провідних українських науковців: Бойченко С., Топільницький П., Гайдай О., Гринишин О., Пушак А. та ін.[2-6].

У наших попередніх публікаціях досліджено якість моторних палив 3 використанням біокомпонентів, вивчено проблеми та перспективи розвитку ринку даної продукції [7-9].

Мета даної роботи: аналіз розвитку ринку моторних палив в Україні та світі, дослідження імпортно-експортних можливостей України. Розгляд стану світового ринку моторних палив допоможе виявити динаміку, спрогнозувати розвиток та оцінити сучасні потреби в такій продукції.

Об'скти дослідження: моторні палива, зокрема, бензини та дизельні палива. Методика проведення досліджень. Використано методи логічного аналізу й узагальнення наукової літератури, статистичних даних щодо експорту й імпорту товарів; застосовано засоби ринкового аналізу Міжнародного торговельного центру (International Trade Center, ITC) [10-11]. Для аналізу торговельних потоків моторних човнів у світі застосовано найбільш вживану класифікацію товарів задля ведення статистики міжнародної торгівлі Гармонізовану систему опису та кодування товарів (далі - ГС) [12].

Виклад основного матеріалу дослідження 3 повним обгрунтуванням отриманих наукових результатів. Структура споживання моторних палив в Україні в останні роки свідчить про високі об'єми споживання дизельного палива, які коливаються біля 6000 тис. т щороку та поступове зменшення споживання бензинів (рис. 1) [13]. Насьогодні працює повноцінно лише Кременчуцький НПЗ, глибина переробки нафти на якому сягає понад $80 \%$. Нафтопродукти Кременчуцького НПЗ є якісними, проте все ж поступаються імпортним. Дефіцит вітчизняних моторних палив значною мірою компенсується завдяки імпорту продукції з Білорусі та Литви. За останні роки значно скоротилась первинна переробка нафти. Якщо у 2013 р. - 3,5 млн. тонн, у 2016 - 2,8 млн. тонн, то у 2019 р. - 0,8 млн. т. (без врахування нафтопереробки Кременчуцького НПЗ) [14]. Частка Шебелинського газопереробного заводу (ГПЗ, Укргазвидобування) у структурі ринку споживання нафтопродуктів в Україні становить 3,8\%: 149 тис. т бензину (більше на 13\%), 88 тис. т дизельного пального (3,5\%) та 176 тис. т скрапленого газу $(6,8 \%)$. Кременчуцький НПЗ (ПАТ «Укртатнафта») виробив 751,8 тис. т бензину (виробництво зросло на 8,5\%), 725 тис. т дизельного пального (11\%) та 108,3 тис. т скрапленого газу (17\%). Його частка на українському ринку постачання нафтопродуктів склала близько $15 \%$. 


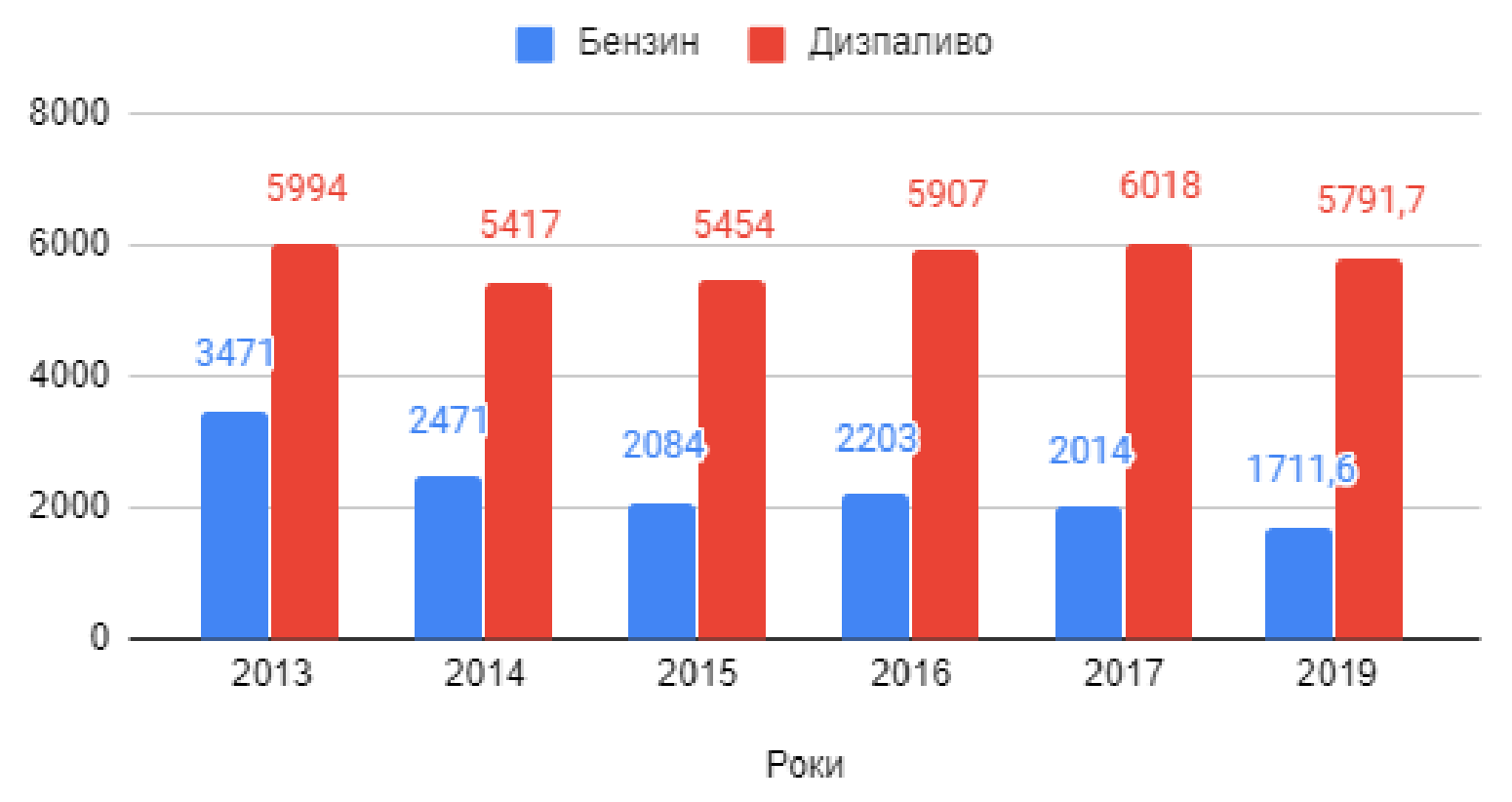

Рис. 1. Структура споживання моторних палив в Україні у 2013-2019 pp., тис. т

Значні темпи падіння спостерігаються й у виробництві дизельного палива для автомобільного та залізничного транспорту. У 2013 р. - 1 млн. т, у $2016-$ 0,63 млн. т, у 2019 році - 0,8 млн. т. Дизельне паливо складає 70 \% у балансі моторних палив України, залежність від імпортних поставок становить майже 90 \%. Це свідчить про нагальність створення диверсифікованої системи поставок, як шляхом збільшення внутрішнього виробництва, так i максимального полегшення імпортних поставок [13].

Імпортовані нафтопродукти часто змішують із низькопробними фракціями, присадками та сурогатними домішками, отримуючи паливо низької якості. За оцінками окремих експертів, собівартість такого палива становить не вище 15 грн/л, а на вітчизняних АЗС воно продається за 25-30 грн./л.

Зважаючи на серйозні порушення техніки безпеки та використання вибухонебезпечних домішок i речовин, якими розводили відносно якісне пальне для збільшення його кількості, на окремих нафтобазах та АЗС в останні роки трапляються пожежі, які завдають непоправної шкоди довкіллю.

Згідно з ГС, бензини і дизпаливо класифікуються в розділі V «Мінеральні продукти», групі 27 «Палива мінеральні; нафта і продукти іiі перегонки; бітумінозні речовини; воски мінеральні», товарній позиції 2710 «Нафта або нафтопродукти, одержані з бітумінозних порід (мінералів), крім сирих; 
продукти, в іншому місці не зазначені, з вмістом 70 мас. \% або більше нафти чи нафтопродуктів, одержаних з бітумінозних порід (мінералів), причому ці нафтопродукти є основними складовими частинами продуктів; відпрацьовані нафтопродукти» [12].

Бензини, які є легкими дистилятами, включаються до товарної підпозиції 271012 «легкі дистиляти та продукти», а дизельне паливо, як важкі дистиляти відноситься до товарної підпозиції 271019 «інші». Ураховуючи зазначене, аналіз торговельних потоків бензинів та дизельного палива в Україні та світі здійснюватимемо за статистичними даними по кодам ГС 271012 та 271019.

Обсяги світового ринку бензинів та дизельного палива $є$ значними, однак динаміка імпорту цих товарів не є стабільною за останні роки (рис. 2) [11].

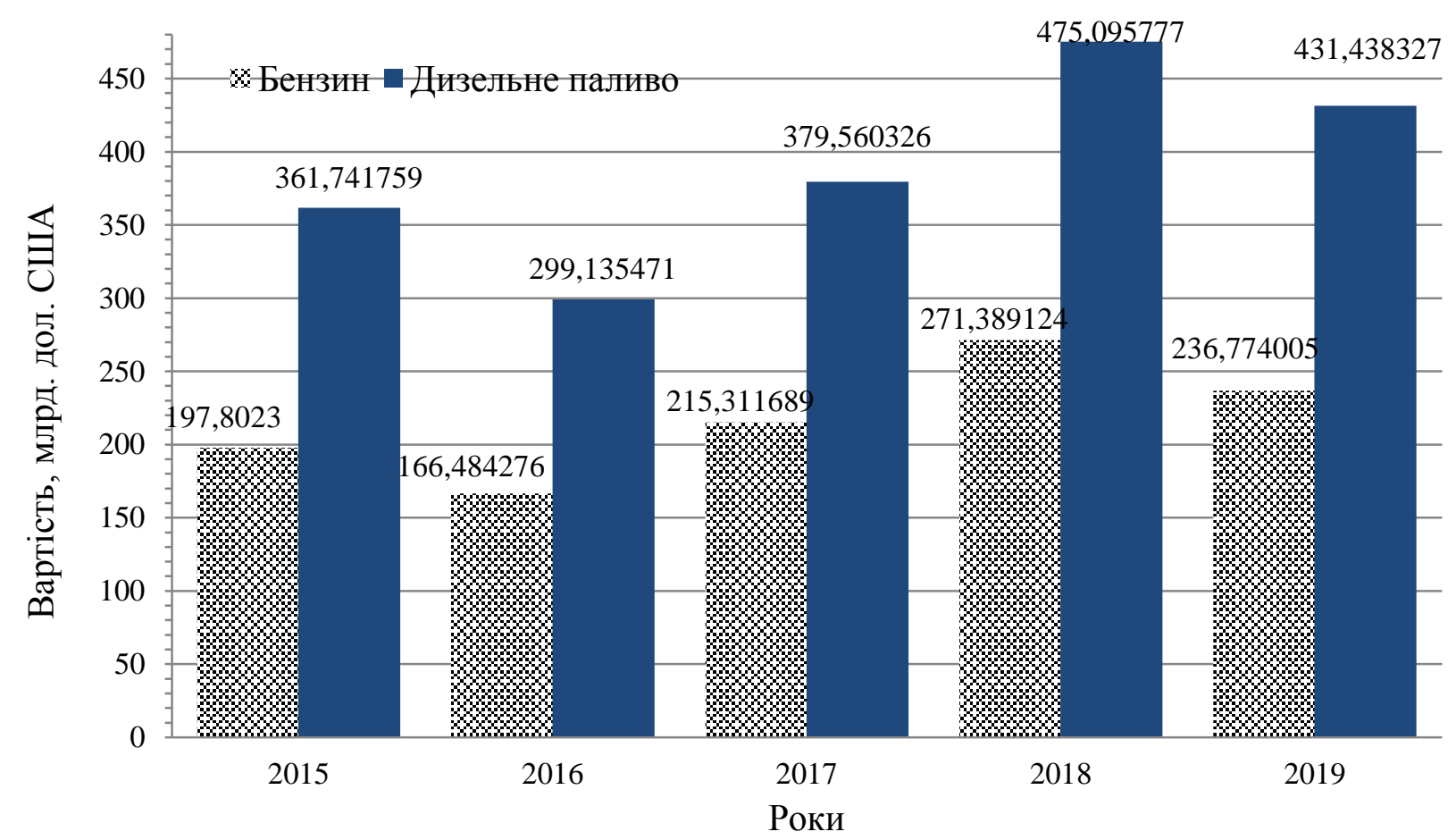

Рис. 2. Обсяги імпорту бензинів і дизельного палива у світі 3а 2015-2019 pp.

У 2019 році обсяги імпорту бензинів і дизельного палива у світі становили 236,77 млрд. доларів США і 431,44 млрд. доларів США відповідно. Загалом тенденцією $є$ те, що у світі дизельного палива ввозиться у 1,8 рази більше, ніж бензинів.

До десятки країн світу, які за останні п'ять років щорічно ввозять до себе більше 3 \% світового імпорту бензинів входять такі країни як: США, Мексика, 
Сінгапур, Корея, Нідерланди, ОАЕ, Японія, Індонезія, Канада та Малайзія (табл. 1.1).

Таблиця 1.Обсяги імпорту країнами світу бензинів у 2015-2019 рр.

\begin{tabular}{|c|c|c|c|c|c|c|c|c|c|c|}
\hline \multirow[b]{2}{*}{$\begin{array}{l}\text { Країни- } \\
\text { імпортери }\end{array}$} & \multicolumn{2}{|c|}{$\begin{array}{c}\text { Обсяги } \\
\text { імпорту у } \\
2015 \text { році }\end{array}$} & \multicolumn{2}{|c|}{$\begin{array}{c}\text { Обсяги } \\
\text { імпорту у } \\
2016 \text { році }\end{array}$} & \multicolumn{2}{|c|}{$\begin{array}{c}\text { Обсяги } \\
\text { імпорту у } \\
2017 \text { році }\end{array}$} & \multicolumn{2}{|c|}{$\begin{array}{c}\text { Обсяги } \\
\text { імпорту у } \\
\text { 2018році }\end{array}$} & \multicolumn{2}{|c|}{$\begin{array}{c}\text { Обсяги } \\
\text { імпорту у } \\
2019 \text { році }\end{array}$} \\
\hline & 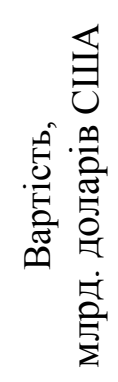 & 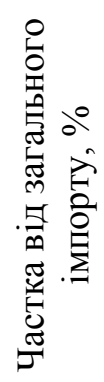 & 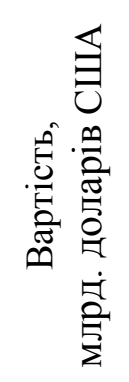 & 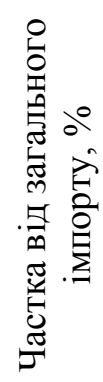 & 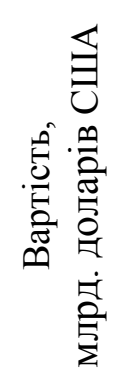 & 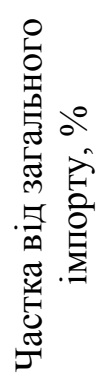 & 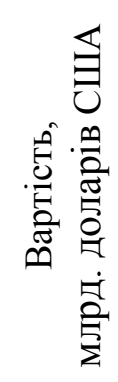 & 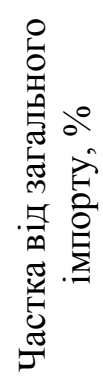 & 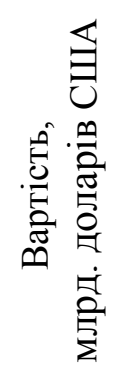 & 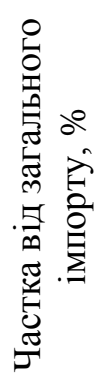 \\
\hline $\begin{array}{c}\text { Усі країни } \\
\text { світу }\end{array}$ & 197,80 & 100,0 & 166,48 & 100,0 & 215,31 & 100,0 & 271,39 & 100,0 & 236,77 & 100,0 \\
\hline США & 20,46 & 10,3 & 18,01 & 10,8 & 19,77 & 9,2 & 24,59 & 9,1 & 25,60 & 10,8 \\
\hline Мексика & 13,41 & 6,8 & 11,68 & 7 & 14,94 & 6,9 & 19,42 & 7,2 & 15,63 & 6,6 \\
\hline Сінгапур & 12,73 & 6,4 & 9,87 & 5,9 & 12,53 & 5,8 & 15,52 & 5,7 & 13,93 & 5,9 \\
\hline Корея & 11,73 & 5,9 & 9,07 & 5,5 & 11,12 & 5,2 & 15,94 & 5,9 & 13,80 & 5,8 \\
\hline Нідерланди & 11,33 & 5,7 & 8,81 & 5,3 & 11,29 & 5,2 & 14,24 & 5,2 & 12,17 & 5,1 \\
\hline OAE & 0,66 & 0,3 & 1,85 & 1,1 & 7,31 & 3,4 & 10,55 & 3,9 & 11,42 & 4,8 \\
\hline Японія & 11,13 & 5,6 & 7,60 & 4,6 & 10,26 & 4,8 & 13,78 & 5,1 & 10,64 & 4,5 \\
\hline Індонезія & 9,17 & 4,6 & 6,77 & 4,1 & 9,27 & 4,3 & 11,07 & 4,1 & 9,66 & 4,1 \\
\hline Канада & 7,21 & 3,6 & 7,52 & 4,5 & 8,30 & 3,9 & 11,15 & 4,1 & 8,76 & 3,7 \\
\hline Малайзія & 6,27 & 3,2 & 4,83 & 2,9 & 6,93 & 3,2 & 8,60 & 3,2 & 7,29 & 3,1 \\
\hline
\end{tabular}

До країн світу, які за останні п'ять років щорічно ввозять до себе більше 3\% світового імпорту дизельного палива входять такі країни як: США, Сінгапур, Франція, Німеччина, Великобританія, Нідерланди, Австралія, Бельгія, та Китай (табл. 2) [11].

Основними країнами експортерами, які $\epsilon$ значними гравцями на світовому ринку бензинів і дизельного палива виступають США, Росія, 
Нідерланди, Сінгапур, Корея, Індія, Китай та Бельгія. При цьому варто відмітити щорічне нарощування поставок цих товарів на світовий ринок Китаєм в останні роки. До десятки країн-постачальників бензину на світовий ринок у 2019 році ввійшли США, ОАЕ, Нідерланди, Сінгапур, Росія, Індія, Корея, Китай, Бельгія та Великобританія (рис. 3) [11].

Таблиця 2. Обсяги імпорту країнами світу дизельного палива

$$
\text { y 2015-2019 pp. }
$$

\begin{tabular}{|c|c|c|c|c|c|c|c|c|c|c|}
\hline \multirow[b]{2}{*}{$\begin{array}{c}\text { Країни- } \\
\text { імпортери }\end{array}$} & \multicolumn{2}{|c|}{$\begin{array}{c}\text { Обсяги } \\
\text { імпорту у } \\
2015 \text { році } \\
\end{array}$} & \multicolumn{2}{|c|}{$\begin{array}{c}\text { Обсяги } \\
\text { імпорту у } \\
2016 \text { році }\end{array}$} & \multicolumn{2}{|c|}{$\begin{array}{c}\text { Обсяги } \\
\text { імпорту у } \\
2017 \text { році }\end{array}$} & \multicolumn{2}{|c|}{$\begin{array}{c}\text { Обсяги } \\
\text { імпорту у } \\
\text { 2018році } \\
\end{array}$} & \multicolumn{2}{|c|}{$\begin{array}{c}\text { Обсяги } \\
\text { імпорту у } \\
2019 \text { році }\end{array}$} \\
\hline & 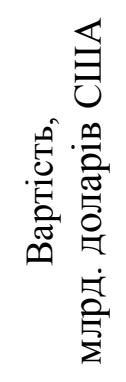 & 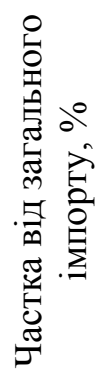 & 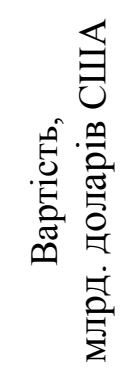 & 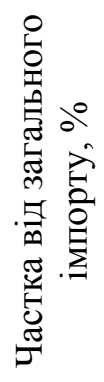 & 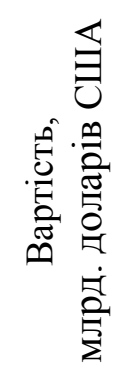 & 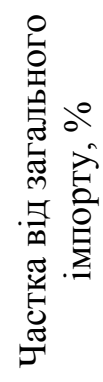 & 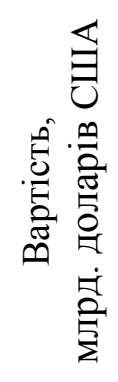 & 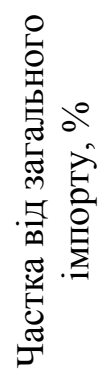 & 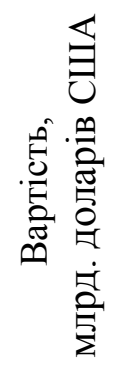 & 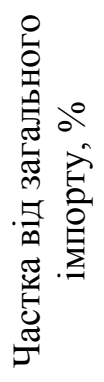 \\
\hline Усі країни світу & 361,74 & 100,0 & 299,14 & 100,0 & 379,56 & 100,0 & 475,10 & 100,0 & 431,44 & 100,0 \\
\hline США & 30,69 & 8,5 & 23,01 & 7,7 & 28,12 & 7,4 & 36,77 & 7,7 & 36,31 & 8,4 \\
\hline Сінгапур & 29,85 & 8,3 & 23,23 & 7,8 & 34,17 & 9 & 38,89 & 8,2 & 31,97 & 7,4 \\
\hline Франція & 17,28 & 4,8 & 13,53 & 4,5 & 15,82 & 4,2 & 20,89 & 4,4 & 20,17 & 4,7 \\
\hline Німеччина & 13,97 & 3,9 & 12,24 & 4,1 & 14,19 & 3,7 & 17,46 & 3,7 & 17,28 & 4 \\
\hline Великобританія & 15,47 & 4,3 & 11,80 & 3,9 & 13,67 & 3,6 & 17,90 & 3,8 & 16,49 & 3,8 \\
\hline Нідерланди & 15,12 & 4,2 & 14,73 & 4,9 & 16,60 & 4,4 & 17,51 & 3,7 & 16,25 & 3,8 \\
\hline Австралія & 10,82 & 3 & 8,64 & 2,9 & 11,74 & 3,1 & 15,74 & 3,3 & 14,43 & 3,3 \\
\hline Бельгія & 9,95 & 2,7 & 8,92 & 3 & 11,34 & 3 & 14,87 & 3,1 & 12,83 & 3 \\
\hline Китай & 10,37 & 2,9 & 7,65 & 2,6 & 10,31 & 2,7 & 14,23 & 3 & 12,80 & 3 \\
\hline Мексика & 6,55 & 1,8 & 6,33 & 2,1 & 9,83 & 2,6 & 13,90 & 2,9 & 11,89 & 2,8 \\
\hline
\end{tabular}

Розглянемо імпорт-експорт моторних палив в останні роки. Загальновідомо, що Україна $\epsilon$ імпортозалежною країною у постачанні моторних палив.

До десятки країн-постачальників дизельного палива на світовий ринок у 2019 році ввійшли США, Росія, Нідерланди, Корея, Індія, Сінгапур, Китай, Бельгія, Малайзія (рис. 4). 


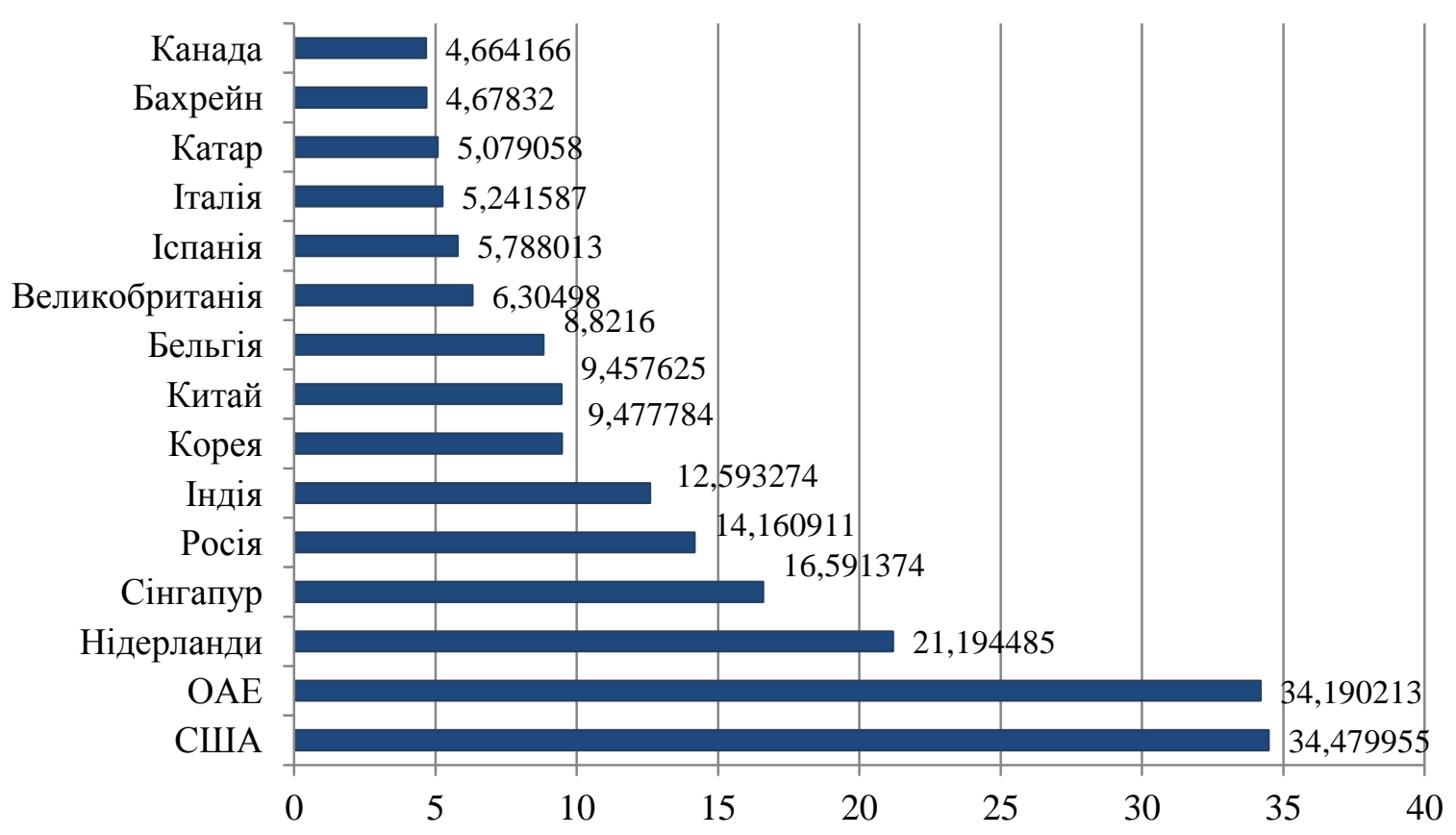

Рис. 3. Обсяги експорту легких дистилятів (код HS 271012) на світовий ринок у 2019 році окремими країнами світу, млрд. доларів США

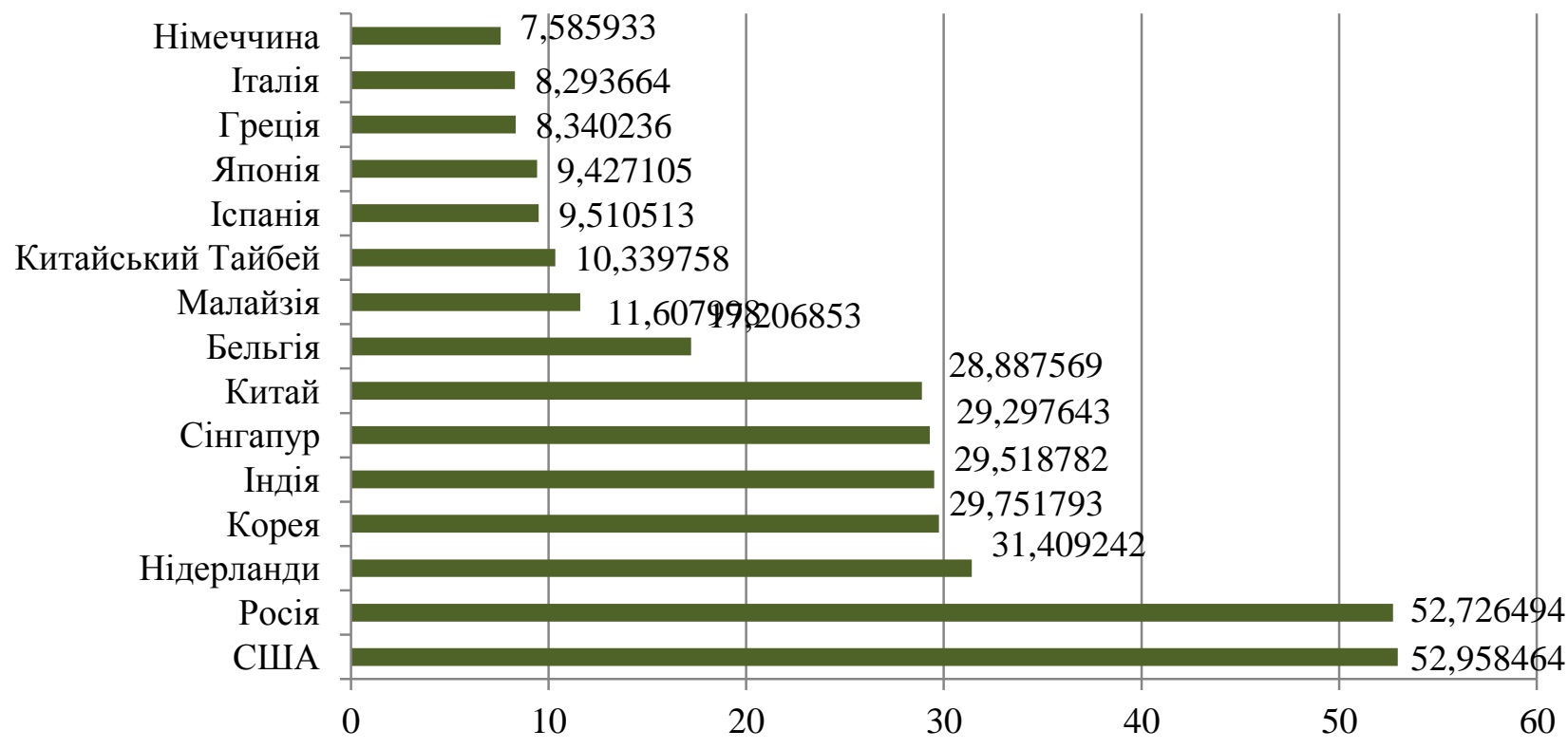

Рис. 4. Обсяги експорту середніх та важких дистилятів (код HS 271019) на світовий ринок у 2019 році окремими країнами світ, млрд. доларів США

Причиною такої ситуації $є$ не здатність вітчизняних нафтопереробних заводів задовольнити попит на внутрішньому ринку. Основним трендом по Україні $є$ 
нарощення обсягів ввезеного бензину і дизельного палива, починаючи з 2016 року (рис. 1.5). У 2019 році в Україну було ввезено дизельного палива на суму 4,46 млрд. США, а бензинів - 0,91 млрд. доларів США. На відміну від загальної тенденції світового імпорту, в Україну ввозиться дизельного палива не в 1,8 рази більше, ніж бензину, а в 3,5 а то і в 4 рази більше, залежно від років.

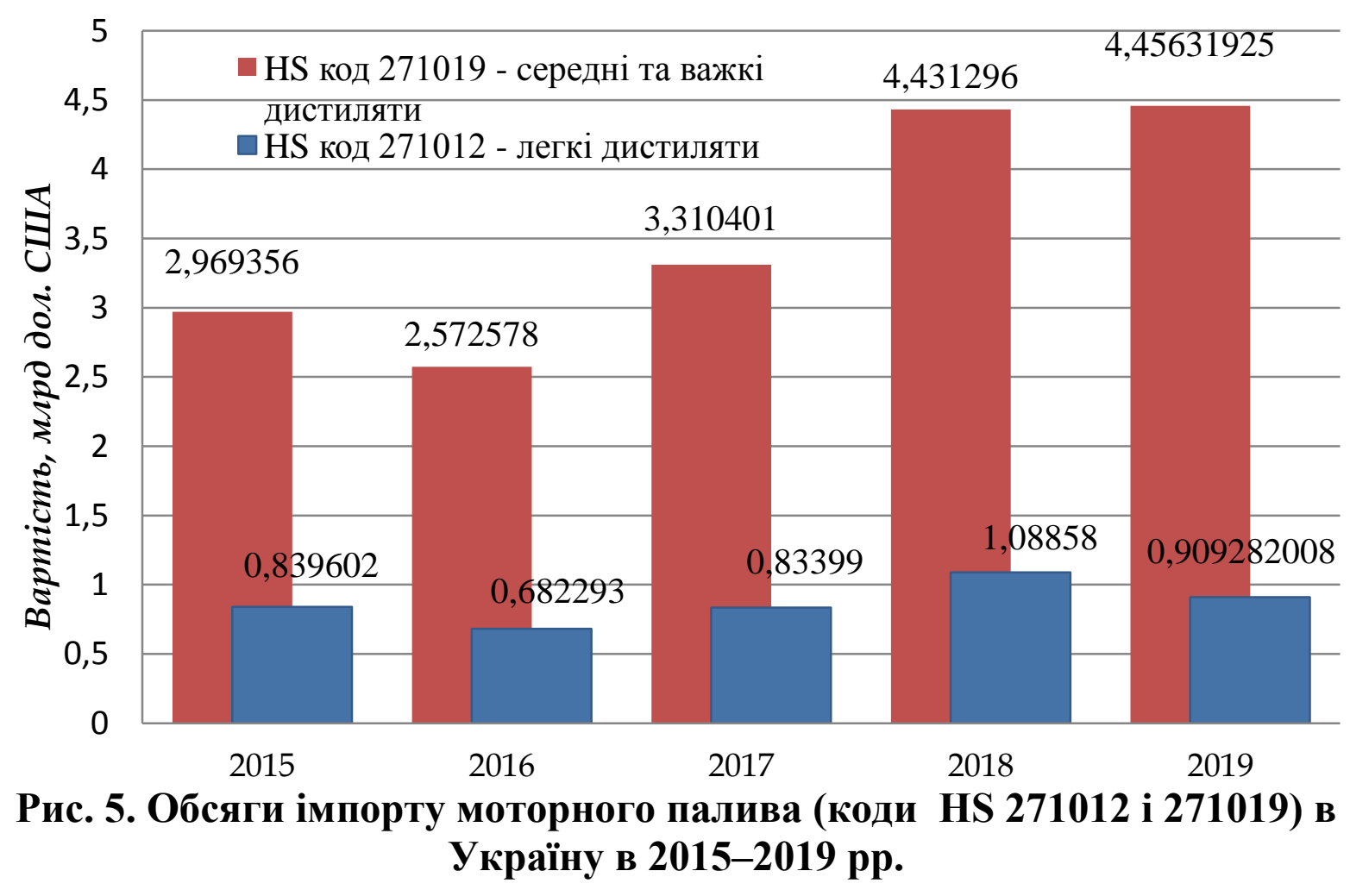

Україна за статистичними даними [2] $є$ експортером моторного палива, зокрема, у 2019 році Україною було продано середніх і важких дистилятів на суму 207,7 млн. доларів США, а легких дистилятів - на суму 59,3 млн. доларів США (рис. 6.).

В умовах загострення зовнішніх ризиків важливою передумовою зміцнення господарської самодостатності України було б якісне підвищення рівня енергетичної незалежності. Але практика господарювання та реальний стан справ у енергетичному секторі економіки засвідчують зворотне: внаслідок відсутності позитивних змін стосовно зменшення енергомісткості готової продукції та збереження негативних тенденцій у виробництві енергоносіїв не забезпечено проривних зрушень у питаннях послаблення залежності від зовнішніх джерел енергозабезпечення.

Корпоративні структури, що працюють в енергетичному секторі національного господарства, володіють достатньою концентрацією 
інвестиційного капіталу для масштабної модернізації, реконструкції та технічного переоснащення техніко-технологічної бази вітчизняних нафтопереробних виробництв i суттєвого збільшення виробництва на них нафтопродуктів, не вистачає політичної волі країни розпочати масштабну реконструкцію вітчизняних НПЗ [15-16].

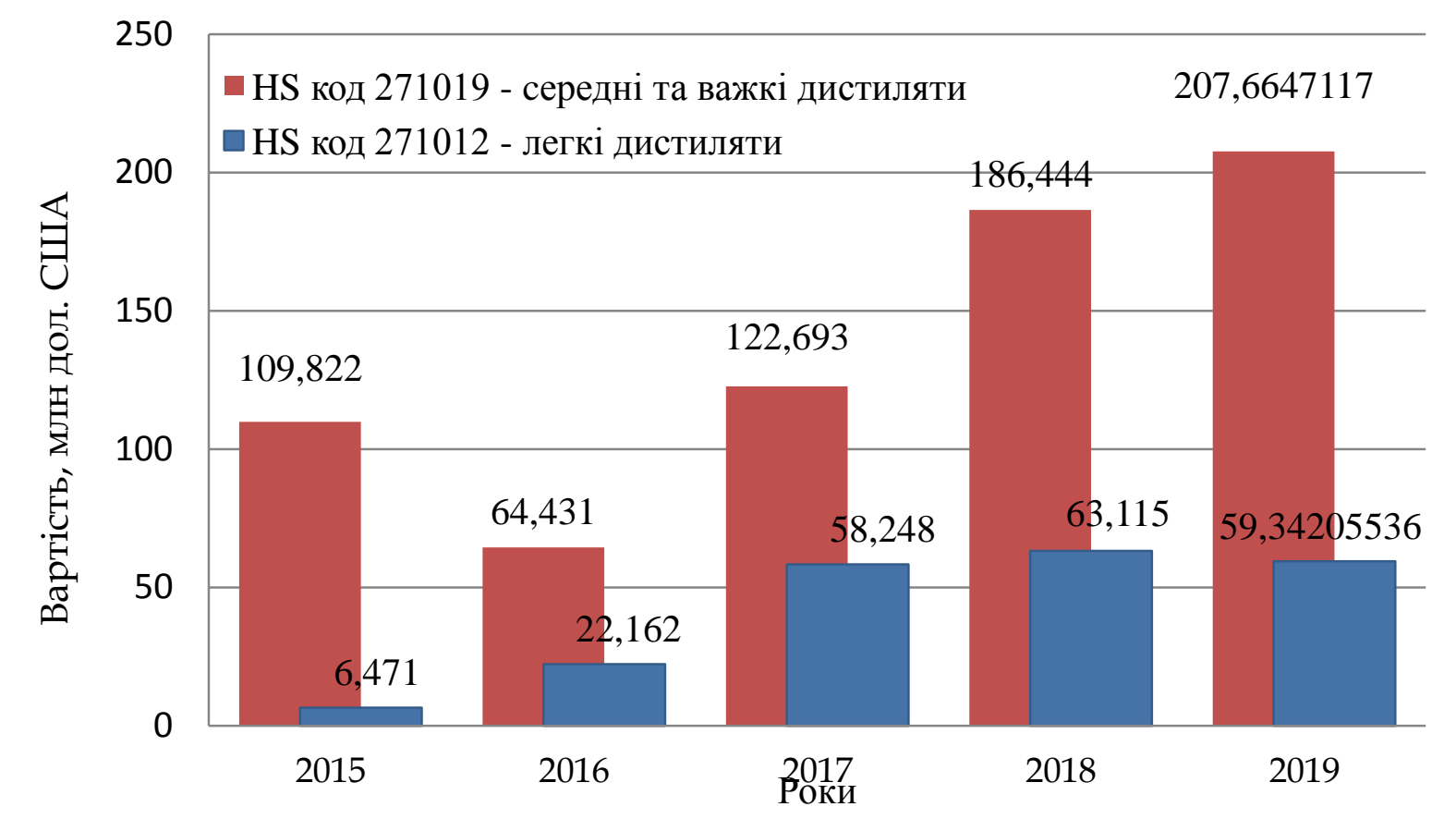

\section{Рис. 6. Обсяги експорту моторного палива (коди HS 271012 і 271019) 3 України в 2015-2019 pp.}

Висновки. Тому пріоритетним напрямами вдосконалення державної політики на українському ринку моторних палив на сьогодні $\epsilon$ : захист державних інтересів в нафтопереробній галузі України; зростання рівня споживання нафти в Україні в коротко- і середньостроковій перспективах, зі створенням максимально можливої доданої вартості підприємствами галузі в країні, із збільшенням виробництва вітчизняного виробництва нафтопродуктів та, відповідно, скороченням обсягів імпорту нафтопродуктів та зниженням залежності від їх імпорту [15]; створення умов для підвищення технологічного рівня, реконструкції, модернізації та нарощення потужностей вітчизняних газота нафтопереробних підприємств, та зростання обсягів і підвищення якості та екологічних норм їх виробництва; підвищення рівня конкурентоспроможності продукції вітчизняних виробників моторних палив на ринку України шляхом 
запровадження рівних та недискримінаційних економічних умов щодо формування їх ціни та імпорту нафтопродуктів; системне вдосконалення i підвищення якості нафтопродуктів, вироблених в Україні; стимулювання нарощування в Україні видобутку нафти з метою збільшення власної ресурсної бази для нафтопереробки, у тому числі, за рахунок створення сприятливих податкових режимів; створення умов для диверсифікації шляхів постачання нафти для забезпечення розвитку нафтопереробки та ринку нафтопродуктів; визначення стратегічних цілей та ролі в економіці України провідних підприємств нафтопереробної галузі, 3 урахуванням потреб економіки та розподілу продуктових сил в Україні.

\section{Список використаних джерел}

1. Гавриленко М. Ключ від всіх дверей: що дасть збільшення нафтопереробки в Україні. URL:

https://www.epravda.com.ua/columns/2020/11/27/668504/?fbclid=IwAR1QYqv9SipYPJsLfD6oJyj PpCoG9n8-AS3LaxVgkiofJPJlaYuNgWEAsZk (дата звернення 01.12.2020).

2. Топільницький П., Гринишин О., Мачинський О. Технологія первинної переробки нафти і газу: підручник Львів: Видавництво Львівської політехніки, 2014. 468 с.

3. Бойченко С., Пушак А., Топільницький П., Лейда К. Моторні палива: властивості та якість : підручник; за заг. 152рму Бойченка С. К.: «Центр учбової літератури», 2017. 324 с.

4. Топільницький П.І., Голич Ю.В., Бойченко С.В. Романчук В.В. Залежність зневоднення нафт від їх фізико-хімічної характеристики. Нафтогазова галузь Украӥни. 2015. № 1. С. 25-30.

5. Гайдай О.О., Зубенко С.О., Полункін С.В., Пилявський В.С. Екологічні та експлуатаційні характеристики палива моторного біологічного Е-85. Матеріали збірника наукових статей III Всеукраїнського з 'їзу екологів. Вінниця: ВНТУ. С. 308-310.

6. Бойченко С.В., Іванов С.В., Бурлака В.Г. Моторні палива і масла для сучасної техніки: монографія. К.: НАУ. 2005. 216 с.

7. Merezhko N., Tkachuk V., Rechun O., Zagoruiko V., Priadko O. Infrared spectroscopy of gasolines with addition of ethanol. Advanced Manufacturing Processes, 2020. P. 442-450. DOI: 10.1007/978-3-030-40724-7_45.

8. Merezhko N., Tkachuk V., Rechun O., Zolotariova O., Romanchuk V. Influence of high-octane bioadditives on physical and chemical properties of low-octane gasoline. Lecture Notes in Mechanical Engineering, 2020. P. 367-376. Doi.org/10.1007/978-3-030-50491-5_35.

9. Ткачук В.В. Дослідження експлуатаційних властивостей дизельних палив 3 біодобавками. Товарознавчий вісник. Збірник наукових праць. 2020. Вип. 6. С. 244-255.

10. Про затвердження Пояснень до Української класифікації товарів зовнішньоекономічної діяльності: Наказ Державної митної служби України від 14.07.2020 № 256. URL : https://customs.gov.ua/documents/pro-zatverdzhennia-perekhidnikh-tablits-vid-uktzedversiyi-2012-r-do-uktzed-versiyi-2017-r-142

11. International Trade Centre. Trade Map. URL: https://www.trademap.org/ (дama звернення 01.12.2020). 
12. Гармонізована система опису та кодування товарів/Harmonized Commodity Description and Coding System. The International Convention on the Harmonized Commodity Description and Coding System (HS Convention) from January 1, 1988.

13. Тенденції ринку нафтопродуктів: можливості 2019 року. URL: https://yurgazeta.com/publications/practice/energetichne-pravo/tendenciyi-rinku-naftoproduktiv-mozhlivosti2019-roku.html(дата звернення: 18.07.2020).

14. Нафтопереробний комплекс України: надії нема, але вихід $\epsilon$ «Енергонезалежність». URL: https://www.5.ua/ekonomika/naftopererobnyi-kompleks-ukrainynadii-nema-ale-vykhid-ie-enerhonezalezhnist-160580.html. (дата звернення: 18.07.2020).

15. Рябцев Г. Причини й наслідки кризи на світовому ринку нафти та їх значення для України. URL: http://visnyk.academy.gov.ua/wp-content/uploads/2013/11/2009-4-13.pdf (дата звернення: 11.08.2020).

\section{References}

1. Gavrylenko M. Kliuch vid vsih dverei: shcho dast zbolshennia naftopererobky v Ukrayini [The key to all the doors: what will increase oil refining in Ukraine]. URL:https://www.epravda.com.ua/columns/2020/11/27/668504/?fbclid=IwAR1QYqv9SipYPJsLfD 6oJyjPpCoG9n8-AS3LaxVgkiofJPJlaYuNgWEAsZk [in Ukrainian].

2. Topilnyczkyj P.I., Grynyshyn O.B., Machynskyj O.Ya. (2014). Texnologiya pervynnoyi pererobky nafty I gazu: pidruchnyk [Primary oil and gas processing technology: a textbook]. L`viv: Vydavnycztvo Lvivskoyi politexniky. $468 \mathrm{~s}$.

3. Bojchenko, A.P. Pushak, P.I. Topilnyczkyj, K. Lejda (2017). Motorni palyva: vlastyvosti ta yakist. Pidruchnyk [Motor fuels: properties and quality. Textbook]. K.: Centr uchbovoyi literatury, 2017. $324 \mathrm{~s}$.

4. Topilnyczkyj P.I., Golych Yu.V., Bojchenko S.V., Romanchuk V.V. (2015). Zalezhnist znevodnennia naft vid yih fizyko-himichnoyi harakterystyky [Dependence of oil dehydration on their physicochemical characteristics]. Naftogazova galuz Ukrayiny [Oil and gas industry of Ukraine]. 2015. № 1. 2015. P. 25-30. [in Ukrainian]

5. Gajdaj O.O., Zubenko S.O., Polunkin Ye.V., Pylyavskyj V.S. (2018). Ekologichni ta ekspluatacijni harakterystyky palyva motornogo biologichnogo E-85 [Ecological and operational characteristics of the motorized biologic engine E-85. Materialy zbirnyka naukovyx statej III Vseukrayinskogo zyizdu ekologiv. Vinnycya: VNTU. S. 308-310.

6. Bojchenko S.V., Ivanov S.V., Burlaka B.G. (2005). Motorni palyva I masla dlia suchasnoyi tehniky: monografiya. K.: NAU. 2005. 216 p..

7. Merezhko N., Tkachuk V., Rechun O., Zagoruiko V., Priadko O. (2020). Infrared spectroscopy of gasolines with addition of ethanol. Advanced Manufacturing Processes, 2020. P. 442-450. DOI: 10.1007/978-3-030-40724-7_45.

8. Merezhko N., Tkachuk V., Rechun O., Zolotariova O., Romanchuk V. (2020). Influence of high-octane bioadditives on physical and chemical properties of low-octane gasoline. Lecture Notes in Mechanical Engineering, 2020. P. 367-376. Doi.org/10.1007/978-3-030-50491-5_35.

9. Tkachuk V. (2020). Doslidzennia ekspluatatsiynyh vlastyvostei dyzelnyh palyv z biodobavkamy [Investigation of operational properties diesel fuel with bioadditives] Tovaroznavchyi visnyk. Zbirnyk naukovyh prats. Vyp. 6, 2020. C. 244-255.

10. Pro zatverdzennia Poyasnen do Ukrainskoyi klasyfikatsiyi tovariv zovnishnyoekonomichnoyi diyalnosti: Nakaz Derzhavnoyi mytniyi sluzhby Ukrayiny vid 14.07.2020 № 256. [About the statement of Explanations to the Ukrainian classification of the goods of foreign economic activity: the Order of the State customs service of Ukraine from 
14.07.2020 № 256]/ URL: https://customs.gov.ua/documents/pro-zatverdzhennia-perekhidnikhtablits-vid-uktzed-versiyi-2012-r-do-uktzed-versiyi-2017-r-142.

11. International Trade Centre. Trade Map. URL: https://www.trademap.org/.

12. Garmonizovana systema opysu ta koduvannia tovariv [Harmonized Commodity Description and Coding System. The International Convention on the Harmonized Commodity Description and Coding System (HS Convention) from January 1]. 1988.

13. Tendenciyi rynku naftoproduktiv: mozhlyvosti 2019 roku [Tendentions of Oilproduct market: possibilities of 2019]. URL: https://yur-gazeta.com/publications/practice/energetichnepravo/tendenciyi-rinku-naftoproduktiv-mozhlivosti-2019-roku.html.

14. Naftopererobnyi kompleks Ukrayiny: nadiyi nema, ale vyhid ye - «Energozalezhnist» [Oil refining complex of Ukraine: there is no hope, but there is a way out - "Energy Independence"]. URL: https://www.5.ua/ekonomika/naftopererobnyi-kompleks-ukrainy-nadiinema-ale-vykhid-ie-enerhonezalezhnist-160580.html.

15. Riabtsev G. Prychyny i naslidky kryzy na svitovomu rynku naftyu ta yih znachennia dlia Ukrayiny [Causes and consequences of the crisis on the world oil market and their significance for Ukraine]. URL: http://visnyk.academy.gov.ua/wp-content/uploads/2013/11/2009-4-13.pdf.

Goal. Analysis of the development of the motor fuels market in Ukraine and the world, research of import and export opportunities of Ukraine. Consideration of the state of the world market of motor fuels will help to identify the dynamics, forecast development and assess current needs for such products.

Results. The main goal of fuel market reform is to reduce import dependence on Russia and its allies with a parallel maximum substitution for Ukrainian products. The main task of developing the market of motor fuels in Ukraine should be to increase the demand for gasoline. It is very important today to reduce the consumption of diesel fuel - the most problematic product from an environmental point of view. In part, this problem can be solved by balancing excise taxes so that gasoline at the gas station is cheaper than diesel fuel. The analysis of the world market of motor fuels showed that diesel fuel is imported by countries 1.8 times more than gasoline, and to Ukraine - 4 times more. It is established that the largest exporters of motor fuels in the world are the United States, the Netherlands, Russia, the UAE, and China is strengthening its position every year.

Practical importance. Consideration of the state of the world market of motor fuels will help to identify the dynamics, forecast development and assess current needs for such products. The analysis of modern Ukrainian realities of the state of the market of motor fuels will allow to outline ways of the decision of existing problems. In the context of exacerbation of external risks, an important prerequisite for strengthening Ukraine's economic self-sufficiency would be a qualitative increase in the level of energy independence. But the practice of management and the real state of affairs in the energy sector of the economy show the opposite: due to the lack of positive changes in reducing energy consumption of finished products and maintaining negative trends in energy production, no breakthroughs have been made to reduce dependence on external energy sources. Corporate structures operating in the energy sector of the national economy have a sufficient concentration of investment capital for large-scale modernization, reconstruction and technical reequipment of the technical and technological base of domestic oil refineries and a significant increase in oil production.

Key words: oil refining industry, gasoline, diesel fuel, export, import.

Стаття рекомендована до друку доктором технічних наук, професором Байдаковою Л.I. Дата надходженняв редакиію 11.01.2021 p. 